\title{
SWART PERSPEKTIEWE OP AFFIRMATIVE ACTION
}

\author{
Kobus Smit \\ Dept. Filosofie \\ Universiteit van die Oranje-Vrystaat \\ BLOEMFONTEIN
}

\begin{abstract}
Affirmative action embodies a model of compensaton justice which aims al counlcructing discrimination on accounn of race, colour, sex or creed. This anicle focuses on race because it has had a devastating effect on blacks in Snuth Africa. The atthor tries to evaluatc the moral ments of affinnative action. An analvsis of the ideas of black Amencan conservatives and a South African academic of a perhaps more liberal mind, is used as a means of questioning the widely prevalen liberal legacy. By highlighting its pretensions and inconsistencies a picture of the implications of affimative action for South Africa emerges that is both a shreat and a challenge.

Equal opportunitics do not necessarily entuil equal results. Other factors such as culture, world view and labour cthos should also be taken into account. The "legacy of dignity" (King) is incompatible wilh the victim-slatus some blacks exploit.

Much was done in South Africa before Julv 1991 that could be labelled affimative action. The scrapping of the Population Registration Act as the last pillar of apartheid has tremendous implications for the dignity of blacks. But histony promises yet a number of traumatic decades of denocratisation of the South African community.

Positively, affirmative action in South Africa will have to focus on quality education, bridging courses to enable black sudents to compete on equal footing for admission, on training employees to qualify for special jobs, community upliftment, housing programmes and the improvemernt of health services. The most urgent need is the cultivation of a common value system.
\end{abstract}

Every man is heir to the legacy of worthiness. Martin Luther King

\section{ONREG EN ONWAARDIGHEID}

In die regsherstellende fase wat Suid-Afrika betree het, veral sedert Junie 1991, is affirmative action brandend aktueel. Regerings- en ANC-beleid verwys daarna. Universiteite stel hulleself op briefhoofde bekend as affirmative action-universiteite. Daar word veel oor die saak gedebatteer en gepubliseer. In die lig van die Ameri- 
kaanse ervaring is dit egter geen probleemlose aangeleentheid nie. Vrae wat voortdurend gevra word, is die volgende: Is affimative action gelyk aan bevoorregting op grond van ras sonder verrekening van meriete of kwalifikasie? Neem voorstanders daarvan kennis van die effektiwiteit en paslikheid van sulke programme? Is daar 'n ideale wyse van kompensering vir geslagtelange onreg? Hoe kan verseker word dat dit 'n tydelike maatreël is? Kan die saak sinvol benader word sonder om te verwys na groepe en groepsregte?

Hierdie artikel fokus op die etiese meriete van affirmative action-programme. Omdat diskriminasie op grond van ras die grootste probleem in Suid-Afrika is, uord daarop gekonsentreer met uitsluiting van diskriminasie ten opsigte van geslag en geloofsoortuiging. Na 'n definiëring van affirmative action word die idees van ' $n$ aantal swart akademici uit Amerika en een uit Suid-Afrika ontleed. Die keuse van swart skrywers is voor die hand liggend. In die slotgedeelte word riglyne vir die etiese hantering van affirmative action-programme in Suid-Afrika aangestip.

Omdat affirmative action gaan oor regsherstel, is ' $n$ beoordeling daarvan onmoontlik sonder 'n peiling van die onreg wat op die spel is. Burton Leiser gee in sy hoek Liberty. Justice, and Morals (1986:334-335) 'n beskrywing van die aard van rassediskriminasie in die VSA. Die voorbeelde wat hy gebruik is tipies Suid-Afrikaans. Dit gaan oor die stemloosheid en dus die magteloosheid van swartes, oor minderwaardige onderwys. swak behuising, die swak infrastruktuur in swart woonbuurte, werkreservering. weiering van toegang tot vakbonde en tot die balie, swakker salarisse, die blokkering van alle geleenthede vir talentvolle swartes wat die kunste betref, segregasie van rasse ten opsigte van busse, treine, restaurante, kafees, hotelle, motelle, openbare biblioteke, swembaddens, parke en grondbesit. Veral gaan dit ook oor gesegregeerde en swak gesondheidsorg. Dis op hierdie soort verontregting in Suid-Afrika wat affirmative action behoort in te speel.

Verontregting is nie net ' $n$ juridiese aangeleentheid nie; dit het morele kante. Om 'n mens oor geslagte heen te degradeer tot 'n derdeklas-burger, beteken om hom te stroop van menswaardigheid en hom te beroof van ontwikkelingsgeleenthede.

\section{WAT IS AFFIRMATIVE ACTION?}

Die term affirmative action word primêr geassosieer met Amerika. Sinonieme is reverse discrimination en positive discrimination (Leiser, 1981:336; Mappes \& Zembaty, 1977:157-161). Dit dui op programme wat sal bevestig (affirm) dat diskriminasie positief beveg word ter wille van die gelyke behandeling van almal. Vir Anthony Giddens (1989:262) dek die term "all programs that take positive steps to redress the 
balance where minority groups are disfavoured." Leiser (1986:339) beskou alle affirmative action-programme as 'n poging om deur positiewe stappe die proporsionele gelykheid in onderwys, behuising, werkvoorsiening, ensovoorts te bewerk (vgl. Bullington \& Ponterotto:17-19).

Die Amerikaanse burgerregtestryd begin in alle erns by die 1954-uitspraak van die Amerikaanse Appèlhof in die saak Brown vs Board of Education. Tien jaar later in 1964 word die Civil Rights Act gepromulgeer. Die doel was om alle diskriminasie te heveg. Artikel 7 van die Civil Rights $A c t$ verbied enige diskriminasie teen enige Amerikaanse burger op grond van ras, geslag, ouderdom, geloofsoortuiging of nasionale herkoms. Algemeen is geoordeel dat dit nie genoeg was om in kleurblinde beleid te volg om die gevolge van diskriminasie te neutraliseer nie. Die posisie van die benadeelde minderheidsgroepe het gegroei oor geslagte heen en dus moes sosiale geregtigheid op 'n meer aggressiewe wyse bevorder word (Leiser. 1986:336). Farley (1982:381) verwys na die metafoor van ' $n$ atleet met gewigte aan sy voete. Om die gewigte halfpad te verwyder, maak dit nie 'n regverdige resies nie. Slegs affimative action kan die posisie regstel.

Verskeie affirmative action-programme is geloods. Een daarvan is die integrasie van skole. Omdat woonbuurte gesegregeer was, is die busing-program ingestel na 'n appèlhofuitspraak in 1971. Dan was daar voorkeur-indiensnemingsprogramme. In 1972 is Artikel VII gewysig deur die Equal Employment Opponunin $A c l$ wat affirmative action uitbrei om alle publieke en private onderwysinstellings en werkgewers (afgesien van die ontvangs van federale fondse) in te sluit (Hitt, 1983:391). Kennedy se doel was nie voorkeurbehandeling nie maar "to ensure that the applicants are employed, and that employees are treated during employment without regard to their race, creed, color, or national origin" (Sowell, 1985:174). 'n Derde aksie het te doen met voorkeurtoelating tot tersiêre onderwysinrigtings.

Programme wat voorkeurtoelating en voorkeurindiensneming van swartes bewerkstellig het, en spesifiek die kwotastelsel, het tot veel konflik en hofsake aanleiding gegee. Hierteenoor is programme wat ingestel is op spesiale onderwysvoorsiening ter wille van 'n gelyke kans vir almal, gunstig ontvang (Leiser, 1986:340).

Drie temas wat steeds weer aangeroer word as affinnative action ter sprake kom, is die venwagtinge van mense met gelyke geleenthede, die moontlikheid van sinvolle diskriminasie en die tydelikheid van programme.

As dit gaan oor die verwagting dat gelyke geleenthede sal lei tot gelyke sosioekonomiese resultate, is die Skotse etikus, Gordon Graham (1988:89) skepties. Sosiale en ekonomiese gelykheid is beslis kenmerke van die ideale samelewing, maar die 
veronderstelde inisiële gelykheid in die argument bestaan alleen teoreties. Die gemeenskapslewe het geen begin soos 'n Monopoly-spel nie. Die ongelykheid in die gemeenskap is 'n feit. Moet indiwidue nou van tyd tot tyd weer op gelyke voet geplaas word? Die entoesiastiese bepleiter van gelykheid sal kies vir hierdie soort inmenging en herverdeling, maar dieselfde persoon word maar weer die underdog (Graham, 1988:80-81).

Die Amerikaanse aggressiewe bemarking van affirmative action is tot absurde konsekwensies deurgevoer wat die vryheid van die indiwidu in gedrang bring en wat daartoe lei dat die opsigtelik beste kandidaat vir 'n pos of studierigting geïgnoreer word bloot op grond van die feit dat hy blank is. Graham wys daarop dat dit in Amerika 'n ernstige belemmering kan wees om 'n talentvolle, heteroseksuele blanke man met geen afwykings te wees. Om dit te omseil, kan mens affirmative action begrens tot die keuse tussen twee kandidate wat gelyk gekwalifiseer is. Daar is egter 'n saak uit te maak vir positjewe diskriminasie. Om 'n blanke onderwyser aan te stel in 'n swart skool as dit aggressie teen blankes onder leerlinge sal bevorder, sou onwys wees. maar as die aanstelling van 'n swart onderwyser in 'n oorwegend blanke skool kan dien om vooroordeel af te breek en so die moontlikheid van 'n vryer, voorspoediger gemeenskap te bevorder, is die feit dat hy swart is 'n aanbeveling (vgl. Graham, 1988:91-96, Maphai, 1989:12-14).

Die derde saak gaan oor die tydelikheid van affirmative action-programme. Graham (1988:97), Farley (1982:381) en andere het 'n definitiewe voorwaarde vir voorkeurindiensneming: dit kan alleen verdedig word as 'n tydelike maatreël wat gemik is daarop om dié soort gemeenskap wat dit noodsaaklik gemaak het, te elimineer. Charles Krauthammer (1990:56) is skepties oor die moontlikheid van die tydelikheid van hierdie lomp, onregverdige en sosiaal demoraliserende verskynsel.

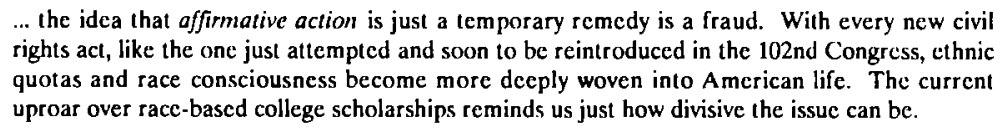

... the idea that affirmative action is just a temporary remedy is a fraud. With every new civil rights act, like the one just attempted and soon to be reintroduced in the 102nd Congress, ethnic quotas and race consciousness become more deeply woven into American life. The current uproar over race-based college scholarships reminds us just how divisive the issuc can be.

(Bush het die ontwerp-grondwet geveto met die argument dat dit die kwotastelsel aanmoedig.)

Krauthammer se oplossing is 'n eenmalige skadeloosstelling van $\$ 100000$ vir elke gesin van vier. Dit sal geweldig baie voorkom wat betref eindelose vervolgings, ongekwalifiseerde allokerings aan 'n groep in plaas van op persoonlike meriete, aan die distorsie van die Amerikaanse beginsel van indiwidualisme en die veragting opgewek deur groepsvoorkeur. Graham aan die ander kant beklemtoon die noodsaaklikheid van nougesette empiriese kontrole van sulke programme met die oog op uitfasering. 
In 'n artikel in Newsweek (Lane, 1991:34-35) kry mens 'n analise van die perspektiewe van swart 'konserwatiewe' denkers in Amerika onder die titel "Defying the Stereotypes". Hulle idees verskil dramaties van die burgerregte-organisasies. Hulle word bloot saamgegroepeer omdat hulle almal heftig krities is oor die burgerregte-paradigma. Onder hulle tel onder andere die pas benoemde hooggeregshofregter Clarence Thomas, die "apostle of black self-reliance", die kongreslid Gary Franks wat glo dat "welfare works against self-sufficiency", Stephen Carter van Yale Law School wat kritiek lewer op rasvoorkeur by indiensneming en promosie en meen dat die doel van affirmative action is om te werk vir 'n situasie waar elkeen beoordeel word aan die hand van dieselfde standaarde, en dan Glenn Loury. Shelby Steele, Thomas Sowell en Walter Williams wat in hierdie artikel bespreek word.

\section{THOMAS SOWELL OOR DIE PRETENSIES EN RESULTATE VAN AFFIRMATIVE ACTION}

Thomas Sowell is 'n swart Amerikaanse ekonoom wat bekroon is vir sy werk oor die ekonomie en politiek van minderheidsgroepe in Amerika. Hy was konsultant van drie administrasies van beide partye. Sowell lewer implisiet kommentaar op die etiese meriete van affimative action. In sy analise beklemtoon hy dat die aksent in die debat stelselmatig verskuif het van gelyke geleentheid na gelyke resultate. Histories beskou, het Artikel 7 van die grondwet niks met "preferential treatment" te doen gehad nie, maar met gelyke geleentheid. Die Equal Employment Opportunity Commission (EEOC) sou kontroleer dat waar meriete bestaan, geen aanstelling geweer word op rassegrondslag nie.

In short, Congress declared itsclf in favor of equal opportunity and opposed to afjinnative aclion. So has the American Public. Opinion polls show a majority of blacks opposed to preferential treatment, as is an even larger majority of women. Federal administrative agencic and the courts led the change from the prospective concept of individual equal opportunity to the prospective concept of parity of group "representation" (Sowcll, 1985:176).

Pres. Johnson se instelling van die Office of Federal Contract Compliance in 1965 het in 1968 sy riglyne oor "goals and timetables" en "representation" uitgevaardig wat kontrakteurs verplig om mense uit minderheidsgroepe (en vroue) verteenwoordigend aan te stel. Die goeie trou van die werkgewers moes bevestig word deur genoemde doelstellings en tydtafels. Eers in 1971 het dit gevorder tot die kwota-stelsel. Hoewel die wet en publieke opinie dit nie vereis het nie, is dit afgedwing deur uitsprake van die Appèlhof. In die Weber-saak het die meerderheidsuitspraak die letterlike interpretasie van die wet verwerp ten gunste van die 'gees' van die wet. Sowell verwerp hierdie interpretasie saam met regter Rehnquist (Sowell, 1985:175-176). Die gevolg van die kwotastelsel was talle hofsake vanaf die sewentigerjare. 
Sowell is dus heftig gekant teen affirmative action as preferential treatment en verwyt die radikale ondersteuners van die burgerregte-idee dat hulle nie insien dat gelyke geleentheid nie noodwendig lei tot gelyke resultate nie. Vir hom bestaan daar talle redes waarom mense verskillende beroepe kies en ekonomies verskillend presteer. $\mathrm{Hy}$ noem naas genetiese redes en diskriminasie, ook demografiese, kulturele en geografiese redes (Sowell, 1985:177).

'n Paar van die voorbeelde uit die talle navorsingsverslae waarna hy verwys, gee 'n indruk van reële faktore wat kan lei tot ongelyke resultate in gelyke omstandigiıede. Beoordeel vanuit 'n konsekwensialistiese etiek kom affirmative action in die lig van hierdie resultate in "n ander lig te staan. Sowell verwys na faktore soos ouderdomsverskille, kulturele verskille soos 'n wiskunde-aanleg, beroepskeuses (" ckonomiese vergoeding, opvoedkundige keuses en prestasies, geografiese verspreiding vin yroepe en die wyse waarop mense werk. Wat kultuurverskille betref: die helfte vain MeksikaansAmerikaanse vroue trou in hul tienerjare teenoor $10 \%$ van Japanee- 4 merikaanse vroue. Hulle opvoedkundige geleenthede en werksopsies word verskrilui terwyl hulle geografies dan nie so mobiel is om werkgeleenthede optimaal te benut nie

Wiskunde-aanleg en prestasie verskil grootliks by verskillende etniese grnepe. Van die hoërskoolkinders in Noord-Carolina skryf $80 \%$ Asiate in vir wiskunde tot en met calculus terwyl slegs $20 \%$ swart studente dit doen. Vir toegang tot sekere gesofistikeerde beroepe is wiskunde 'n voorvereiste wat impliseer dat Asiate ekonomies noodwendig beter vaar.

Nasionale resultate in die Scholastic Aptitude Test (SAT) vir studente wat aansoek doen vir toelating tot kolleges, toon dat Asiate en blankes konsekwent beter vaar as Spaans-Amerikaners en swart studente. Dit geld ook waar sosio-ekonomiese gelykheid bestaan en daar dus nie verwys kan word na omgewingsverskille nie. Swartes, Meksikaanse Amerikaners en Amerikaanse Indiane uit families met 'n inkomste van $\$ 50000$ en meer vaar swakker as Asiate uit families met 'n inkomste van $\$ 6000$ en minder. Kultuurverskille is dus vir hom 'n werklikheid wat nie weggeredeneer kan word met verwysing na beledigende stereotipes of rassisme nie (Sowell, 1985:178).

Die belangrikste saak wat hy aanroer is die verskil in arbeidsetos. Mense verskil in die wyse waarop hulle werk: fluks, versigtig, samewerkend, getrou, sonder die noodsaaklikheid van toesig en waarskuwings oor afwesigheid, slordigheid en drankmisbruik of andersom.

Not only are such things inherently difficult to quantify, any suggestion that such differences even exist is sure to bring forth a storm of condemnation. In short, the civil rights vision has been hermetically sealed off from any such evidence (Sowell, 1985:180). 
Enige historiese en tydgenootlike waarnemings oor intergroepsverskille in werkswyse, dissipline, betroubaarheid, netheid en 'n gesindheid van samewerking word outomaties van die tafel gevee as bewys van vooroordeel. Noem net die towerwoord stereotipes en enige verdere nadenke word onnodig. Hy verwys na die voorbeeld van boere waar werkgewergesindheid nie 'n faktor kan wees nie en vra waarom Duitse boere beter presteer as lerse boere? Waarom mag daar nie melding gemaak word van Duitse boere se hardwerkendheid, spaarsaamheid en soberheid van lewenstyl nie? Waarom verdien Jode meer as Spaanssprekende Amerikaners in New York? Diskriminasie? Waarom verdien Jode ook meer in Spaanssprekende lande dwarsdeur Latyns-Ameri$\mathrm{ka}$ ?

Sowell gaan ook in op die effek van affirmative action. Hy vestig die aandag daarop dat tendense tot demokratisering en distributiewe geregtigheid reeds voor die Civil Rightts $A c t$ op dreef was. Veel word gemaak van die teenwoordigheid van swartes in hoëvlakposte sedert 1964 maar in die periode 1954-1964 het die aantal swartes in professionele. tegniese en ander hoër poste reeds verdubbel. Die aantal swartes in professionele en tegniese poste vir die twee jaar 1964-1966, was minder as vir die een jaar 1961-1962.

Persentasiegewys het die Civil Rights Act van 1964 geen versnelling in die proses beteken nie; inteendeel, die persentasie swarl tegniese en professionele werkers het afgeneem in die daaropvolgende vyf jaar in vergelyking met die vyf jaar voor die promulgering van die wet (Sowell, 1985:181-182). Dieselfde tendens geld vir Asiate en Spaans-Amerikaners.

Die gesinsinkomste van swartes in vergelyking met blankes en die nasionale gemiddelde, krimp steeds. Swart eenouer-gesinne was in die sewentigerjare die armste en hul inkomste toon die stadigste toename. Hul posisie verswak vanaf $70 \%$ van blanke inkomste in 1970, tot $62 \%$ daarvan in 1980 .

Sowell is diep bewus van die positiewe politieke gevolge van die Civil Rights $A c t$ ten opsigte van swart verteenwoordiging op enige vlak (veral in die Suide), maar die oortuiging dat die Civil Rights $A C t$ en affirmative action 'n dramatiese invloed op die ekonomiese vooruitgang van minderheidsgroepe gehad het "have become part of the folklore of the land, established primarily through repetition and vehemence, rather than evidence" (Sowell, 1985:182).

Volgens hom sal hofsake voortduur en sal die metodes wat die howe en die politiek gebruik om diskriminasie te meet, verseker dat dit nog lank 'n bron van twis sal bly (Sowell, 1985:189).

Behalwe die oorwegings in verband met koste en effektiwiteit, verwys Sowell (1990:15-

Koers $57(1)$ 1992:31-57 
16) ook na ander oorwegings. Programme is allermins tydelik van aard. Dit word voortgesit en groei in skopus om al meer groepe in te sluit. Selfs waar wetlikvasgestelde beëindigingsdatums bestaan het soos in Indië en Pakistan, is dit telkens verleng. Binne groepe wat deur regeringsmaatreëls bevoordeel is, was daar 'n oneweredige verspreiding sodat die meer bevoorregtes meer gekry het. Groeppolarisasie het toegeneem en selfs gelei tot bendegeweld en burgeroorlog. Valse aansprake op lidmaatskap van die hevoordeelde groepe het wyd voorgekom.

\section{GLENN C. LOURY OOR DIE MORALITEIT VAN VOORKEUR INDIENSNEMING}

Vir die beoordeling van die etiese meriete van affirmative action-programme, is die gedagtes van die swart Amerikaanse politieke ekonoom (John F. Kennedy School of Government, Harvard Universiteit) Glenn Loury, belangrik. Hy is geen radikale individualis nie maar 'n neo-konserwatis met gedefinieerde ideale vir swart Amerikaners. Hy is 'n erkende kritikus van burgerreg-leierskap en glo nie dat publieke burokrasieë kan vergoed vir privaat inisiatief nie. Hy is diep besorgd oor die vermorsing van menslike potensiaal in die ghetto's van Amerika en ontsteld oor die min vordering wat die owerheid gemaak het met die verligting van die lyding wat daar voorkom (Loury 1990:15).

Die Civil Rights Movement was volgens hom rewolusionêr daarin dat dit weggedoen het met die wetlik afgedwonge tweedeklas-burgerskap van die Neger. Dit het ontsaglik veel beteken vir hul belewing van menslike waardigheid. Die veranderinge geld veral die terreine van opvoeding, arbeid en verkiesingspolitiek. Die grootste uitdaging vir die burgerregtebeweging was die sosio-politieke agenda (Loury, 1985:9). Ten spyte van die radikale omwentelinge en die affirmative action-programme, het die ideaal van sosiale en ekonomiese gelykheid egter hoegenaamd nie gerealiseer nie (Loury, 1990:12).

Hy maak melding van Martin Luther King se rede in 1961 by Lincoln Universiteit waar hy verwys het na "God-given ... human rights" en die "legacy of worthiness" waarop elke mens geregtig is en vervolg dan met 'n ontleding van die spanning wat daar in die gemoed van die gekultiveerde Neger leef. 'n Meer gedifferensieerde diagnose het noodsaaklik geword. Wit rassisme kan nie meer eksklusief die skuld dra vir die sosiale patologie van die swart ghetto-gemeenskap nie. Rassisme is een faktor, maar verantwoordelikheid om die situasie te hanteer is 'n ander.

For no people can be genuincly free so long as they look to others for their deliverance. The pride and self-respect valued by aspiring peoples throughout the world cannot be the gift of 
outsiders - they must derive from the thoughts and deeds of the peoples themselves. Neither the guilt nor the pity of one's oppressor is a sufficient basis upon which to construct a sense of selfworth (Loury, 1985:11).

In sy analise van die situasie van swart Amerikaners verwys hy na die hoë werkloosheidsyfer, na die feit dat meer as $50 \%$ van geboortes buite-egtelik is, dat staatsafhanklike gesinne verdubbel het sedert 1964 , dat ongeveer $40 \%$ van die mense wat in Amerika vermoor word, swart mans is wat deur swart mans vermoor word, dat die helfte van die gevangenes swart is terwyl die Negers $10 \%$ van die bevolking uitmaak, dat die risiko vir verkragting in stedelike gebiede vyf keer groter is vir swart vroue (Loury, 1990:13).

Hierdie feite spreek van 'n wanhopige situasie en 'n fundamentele vervreemding waarvoor daar vanuit twee ideologieë twee teenoorstaande redes aangevoer word. Die liberalisme skryf dit toe aan 'n tans meer subtiele vorm van rassisme. Werkloosheid onder die swart jeug is die produk van die weiering van werkgewers om bekwame en flukse jongmans in diens te neem op grond van hulle ras. Afhanklikheid van welsyn is die gevolg van gebrek aan geleentheid. Kriminaliteit is die gevolg van die vooroordeel van polisie en regters.

Aan die ander kant word die situasie deur die konserwatiste toegeskryf aan die dwase welvaartstaat-idee van liberaliste. Beleidsprogramme het op min of niks uitgeloop. Benign neglect is die aangewese houding. Hierdie twee ideologieë teer wedersyds op mekaar.

In eersgenoemde geval is die enigste opiossing om meer te spandeer aan sosiale programme. Enige navraag oor koste-effektiwiteit en paslikheid word binne hierdie konteks 'n bewys van onbetrokkenheid. Enige affirmative action, of dit tegniese opleiding vir armes van die ghetto's is of 'n stewige munisipale kontrak vir 'n swart miljoenêr, is noodsaaklik en regverdig in die lig van die geskiedenis van rasse-onderdrukking. Die konserwatiewes daarenteen is gebelgd oor die idees van burgerregleiers en die mislukking van sosiale programme en verkies om die rasseprobleem nie aan te roer nie maar bloot in formele terme oor die 'kleurblinde staatsoptrede' te praat.

Loury beskou die kritiek van konserwatiewe kant as geregverdig. In sy soeke na 'n verklaring vir die mislukking van die affirmative action-programme, raak hy dan die belangrike kwessie van die ontwikkeling van 'n nuwe waardesisteem aan. Amerikaners word toenemend bewus van die argeloosheid wat bestaan ten opsigte van die relevansie van waardes in gedrag, van die aversie om persone aanspreeklik te hou vir die optredes wat hul afhanklikheid veroorsaak en dat 'die gemeenskap' altyd die skuld moet dra vir alle ongeluk in die wêreld. "Characterizing the problem of the ghetto poor as a function of white racism is one variant of the 'society is guilty' argument. It 
overlooks the extent to which values and patterns of behavior of inner-city black youths are implicated in the difficulty" (Loury, 1990:14).

Loury beklemtoon self-help as oplossing. Hy is krities oor die voorkeurbehandeling by indiensneming en toelating en pleit dat afgestap sal word van die mens-onterende slagoffer-mentaliteit, want dit stroop die mens van sy waardigheid, is self-veroorsaak en lei tot 'n situasie waar indiwiduele sukses gesien word as verraad teen swart belange (Loury, 1990:19). Die prys vir die rol van slagoffer te speel, is onvervulde lewens en ongerealiseerde persoonlike potensiaal wat gelyk is aan "the loss of our souls".

Miljoene ander immigrante maak 'n sinvolle bestaan in Amerika (Loury, 1990:16). Wie glo in die vryheid van die indiwidu maar nogtans passief wag op wit Amerikaners om hulle te red. maak $\mathrm{n}$ bespotting van daardie vryheid. As swartes met gelyke kanse afhanklik bly. het hulle hul aanspraak op waardigheid en die respek van medeburgers verbeur. 'n Vrye volk aanvaar verantwoordelikheid vir sy eie lot al lê dit nie geheel in sy eie hande nie (Loury, 1990:16). Die inkonsekwentheid dat swartes aan die een kant staatmaak op kwotas en aan die ander kant 'ware gelykheid' propageer moet in behandeling geneem word. Die klem op persoonlike verantwoordelikheid kanselleer nie die reuse regeringsverpligting ten opsigte van die belange van sy burgers nie. Hierdie verpligting geld onderwys, tegniese opleiding, die implementering van anti-diskriminasie-wetgewing en die voorsiening van minimum onderhoud.

Daar is egter sekere dinge wat 'n regering nie kan doen nie. Die uitbouing van gemeenskapswaardes en die kultivering van verantwoordelikheid in arbeid, gesinslewe en onderwys hoort in die hande van private, vrywillige assosiasies soos kerke, gesinne, buurtgroepe. Die normative health van die groep is ook die verantwoordelikheid van die intellektuele, politieke en religieuse leiers van die swart gemeenskap (Loury, 1985:12). Hiervoor is diskussies van waardes en persoonlike houdings nodig. Hy vind dit jammer dat hierdie diskussies geweer is deur die betrokke leiers. Die regering kan nie die taak op hom neem om die waardes en oortuigings van segmente van die samelewing te bespreek of tc probeer bepaal nie. Niemand buite die swart gemeenskap kan dit in elk geval waag om hierdie sake te berde bring nie want hulle status as 'liberaliste' sal onmiddellik in die gedrang kom:

Only blacks can talk about what other blacks "should" do, think, or valuc and expect to be sympathetically heard. That is, only blacks can effectively provide moral leadership for their pcoplc (Loury, 1985:15).

Die styl om voorregte deur die hof te verwerf, moet laat vaar word.

The inescapable truth of the matter is that no judge can mandale excellence. No selection commiltce can create distinction in black scholars. No amount of circuitous legal mancuvering 
can obscure the social reality of inner-city black crime ... No degrec of double-standard setting can make black students competitive or comfortable in academically exclusive colleges and universities (Loury, 1990:17).

Wat is dan die uiteindelike ideaal as dit nie affirmative action-programme is nie? Loury meen:

... to be actively engaged in trying to change the structures that constrain the black poor in such a way that they can more effectively assume responsibility for themselves and excrcise their inherent and morally required capacity to choose (Loury, 1990:18).

Die pad van persoonlike verantwoordelikheid is die waarborg vir "the legacy of worthiness".

\section{SHELBY STEELE OOR SWART IDENTITEITSERVARING}

Steele (adjunk-professor in Engels, San Jose Staatsuniversiteit) benader affirmative action vanuit ' $n$ meer sielkundige perspektief. In sy artikel "Being Black and Feeling Blue" verwys hy na swartes se enorme opofferinge om hul vryheid en gelykheid voor die wet te verwerf en die latere reaksie daarop. Soos Sowell en Loury verwys hy na die verslegtende situasie van swart Amerikaners. Die swart middelklas wat in die sewentigerjare gegroei het, het in die tagtigerjare weer teruggesak terwyl die swart onderklas voortdurend gegroei het. Swartes vermy uitdagings omdat hulle hul selfvertroue verloor het. Hy noem dit die mees tragiese sosiale ironie van die twintigste-eeuse Amerikaanse situasie dat swartes meer gelykheid en geleenthede verwerf het, maar sosiaal-ekonomies en andersins verder teruggeval het by blankes as voor die Civil Rights Movement (Steele, 1989:498). Om sy oordeel te staaf, verwys hy na die verslae van die Chicago Universiteit, die Nasionale Navorsingsraad en die Kerner-kommissie (Steele, 1990:498). Affirmative action-programme was sinloos omdat swartes nie beskik oor die ontwikkeling om sinvol daarvan gebruik te kan maak nie (Steele, 1990:499).

Die feit dat swartes staatmaak op die skuldgevoel van blankes om met meer vorendag te kom as "fairness", naamlik "reparation and compensation", het daartoe gelei dat die klem al meer geval het op dit waarop swartes geregtig is en nie op hul ontwikkeling nie (Steele, 1990:503).

Steele het dit dan veral oor integrasieskok en rassevrees.

"Racial anxiety" maak dit vir die swarte onmoontlik om sy plek in die hoofstroom van die Amerikaanse lewe in te neem. Hierdie vrees is erger as die diskriminasie - wat steeds bestaan. 
The condition of being black in America means that one will likely endure more wounds to one's self-esteem than others and that the capacity for self-doubt born of these wounds will be compounded and expanded by the black race's reputation of inferiority ... Black skin has more dehumanizing stereotypes associalted with it than any other skin color in America, if not the world. When a black presents himself in an integrated situation, he knows that his skin alone may bring these stereotypes to tife in the minds of those he meets and that he, as an individual, may be diminished by his race before he has a chance to reveal a single aspect of his personality (Stcele, 1989:501).

Omdat sy swart vel hom beskuldig van rasseminderwaardigheid, beteken vclkleur vir hom weerloosheid, "a relentless openness to diminishment and shame". Dit gaan primêr dus nie meer oor rassisme in die gemeenskap nie, maar die rassis in die persoon van die swarte self wat niks besorgd is oor burgerregte en gelyke geleenthede nie, maar wat behep is met die wond wat deur die onreg veroorsak is (Steele, 1989:502).

Die oordrewe beheptheid met rassetrots by Amerikaanse swartes word ook deur Steele onder verdenking geplaas. Hy verwys na die nuwe naam wat onlangs in omloop gebring is, naamlik African-Americans. Trots volg op egte vooruitgang. Nuwe name spreek van onsekerheid. In die sestigerjare het die naam black sin gehad "because it was not a denial but a confrontation of inferiority anxiety, with the shame associated with the color black".

Vervolgens behandel hy integration shock, iets waarmee swartes sedert 1964 worstel. Hy vind dit ironies dat swartes beskerm is teen hulle rasse-weerloosheid juis deur die ongelyke geleenthede en die ander onderdrukkende maatreëls van segregerende wetgewing. In 'n gesegregeerde gemeenskap bestaan daar nie dieselfde aanspreeklikheid vir swartes nie.

Die weerloosheid het toegeneem eweredig met vryheid en geleentheid. Vryheid impliseer altyd die skok van aanspreeklikheid. "(It) made us individually and collectively more accountable to the myth of black inferiority and therefore more racially vulnerable" (Steele, 1989:504).

Steele onderskei drie tipiese reaksies op integrasie-skok: die tendens om minimaal gebruik te maak van geleenthede of dit te vermy, die tendens tot halfhartige insette op terreine waar swartes gewoonlik nie presteer het nie en die tendens om te segregeer in geïntegreerde situasies. As gevolg van min selfrespek word geleenthede ervaar as geleenthede om te misluk. Dit moet die rede wees waarom die getal swart studente in kolleges drasties verminder het en waarom entrepeneurs-geleenthede in swart gemeenskappe nooit deur swartes self nie, maar deur immigrante opgeneem word. Wat die tendens tot minimum-inset as gevolg van die min selfvertroue betref, verwys hy na die gebrek aan toewyding in die skool, werk en gesinslewe. Hierteenoor is die houding van 
swartes op terreine waar hulle tradisioneel presteer soos sport en musiek, totaal anders. Hier is swartes, anders as in die klaskamer, ten volle betrokke. Die derde tendens kom tot uitdrukking daarin dat swartes op oorwegend blanke kampusse kontak met blankes vermy en hulleself organiseer in swart studente-organisasies en koshuise. Swart studente is gemaklik in die teenwoordigheid van ander swart studente. Steele vind dit verbasend dat hulle op aparte fasiliteite aandring en terselftertyd betoog teen apartheid. Wit skuld het daartoe gelei dat swart studente hulleself sien as 'n aparte spesie vir wie normale standaarde en waardeș nie outomaties geld nie. Universiteitsadministrateurs se toegewings aan swart studente gee sanksie aan rasseseparatisme. Die wit skuldgevoel lei tot spesiale "entitlements" wat veel verder gaan as "fairness". Dan vervolg hy:

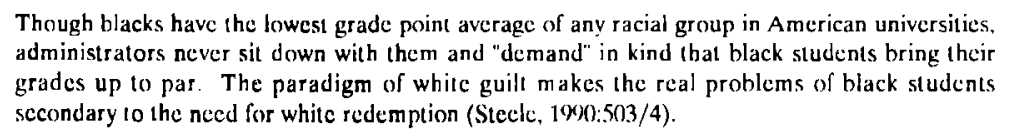

Though blacks have the lowest grade point average of any racial group in American universities, administrators never sit down with them and "demand" in kind that black students bring their grades up to par. The paradigm of whitc guilt makes the real problems of black students sccondary 10 the need for whitc redemption (Stecle, 1\%0):503/4).

Hy verwys na Pennsylvania Universiteit waar swart studente wat hul punte kan verbeter geldelik beloon word: vir 'n verbetering van 'n C na C+ kry hulle $\$ 550$ en vir enigiets meer $\$ 1000$ (Steele, 1990:505). Vir hom is daar geen beter weg om die spyker van minderwaardigheid in te slaan nie.

Wat mens behoort na te streef is nie 'n sosiale beleid wat swart armoede aanspreek nie. maar armoede as sodanig - en 'n beleid wat daardie waardes aanmoedig wat mense laat staatmaak op hulleself. Die boodskap van blanke Amerikaners moet wees: "America hust you badly and that is wrong, but entitlements only prolong the hurt, while development overcomes it" (Steele, 1990:506).

Een van die relevante opmerkinge wat hy ten slotte maak, is dat onderdrukking nie ophou wanneer die onderdrukker daaroor berou het nie, net so min as wat die onderdrukker dan ontslae is van sy skuldgevoel. Twyfel en skuld bestaan lank voort. "I think black Americans are today more oppressed by doubt than by racism and that the second phase of our struggle for freedom must be a confrontation with that doubt" (Steele, 1989:508).

Steele se beklemtoning van die feit dat rassediskriminasie minderwaardigheid diep inbrand in die grein van die slagoffers daarvan, moet ernstig opgeneem word in die beoordeling van swart Suid-Afrikaners se reaksies in politieke debatte, skole, universiteite, kerkvergaderinge, ensovoorts. Die beoordeling van affirmative actionprogramme sal rekening moet hou met hierdie emosionele letsels. Die black is beautiful-sindroom in die Amerika van veral die laat sestigerjare (Steele, 1990:497), sal ook in Suid-Afrika nog lank voortbestaan. As Steele (1989:507) in sy konteks kan sê: 
"Somewhere inside every black is a certain awe at the power and achievement of the white race", sal dit nog baie lank neeın vir die meeste swartes in Suid-Afrika om hulle te ontworstel aan die mite van minderwaardigheid.

\section{WALTER WILLIAMS}

Walter Williams is professor in ekonomie aan die George Mason Universiteit. Hy het verskeie toekennings vir sy werk ontvang en het in 1989 onder andere 'n werk gepubliseer oor South Africa's War Against Capitalism.

In sy bespreking van affirmative action verwys hy na die feit dat Afrikaners ook gelei het onder Engelse en Joodse ekonomiese oorheersing en nou dieselfde soort onreg pleeg teenoor swartes. Apartheid is deel van 'n beleid van affirmative action vir Afrikaners.

Hy konsentreer in sy artikel op die kwotastelsel as 'n onvermydelike gevolg van die verrekening van ras en etnisiteit in ekonomiese besluitneming. Wanneer 'n owerheid voorregte toeken aan een burger impliseer dit 'n nadeel vir ' $n$ ander. Enıge werkreservering op grond van ras loop hierop uit. Vir hom kan die effek van affirmative action nie gemeet word aan getalle nie. Hy verwys na swart Amerikaners wat 13\% van die bevolking uitmaak maar $75 \%$ van die professionele korfbalspelers, $55 \%$ van die voetbalspelers en $38 \%$ van die bofbalspelers uitmaak. Oor geregtigheid in sport sê dit niks. Daar moet eerder gekyk word na die proses: neutrale reëls, 'n spel volgens die reëls, vrywillige deelname, 'n onbevooroordeelde skeidsregter, ensovoorts.

Die uitdaging vir Suid-Afrika is om die proses te ondersoek en toe te sien dat die reëls vir die spel billik is. Dit moet gaan oor menslike geregtigheid en nie oor rassegeregtigheid nie. Die soewereiniteit van die wet is die eerste reel en dit impliseer gelykheid voor die wet. Elke regeringsamptenaar moet ewe aanspreeklik wees voor die wet en elke wet moet as doel hê die beskerming van die vryheid van indiwidue. Behalwe dat alle apartheidswetgewing geskrap moet word, het hy dit veral oor onnodige beheermaatreëls oor handel, oor wette in verband met regerings- en privaatmonopolieë en oor bevoorregting van sommige ten koste van andere. Hy verwys instemmend na die gedagtes van Sowell dat dit nie net gaan oor kompensasie vir gelede onreg nie, maar dat die koste en effektiwiteit van affirmative action ook ter sake is en dat dit tydelik van aard behoort te wees, ensovoorts.

As al die besware van Sowell en andere dan geldig is, waarom is affirmative actionprogramme dan so gewild? Sy antwoord is belangrik: 
Affirmative action programmes give the illusion of commitment and the promise of widespread gain. Any gains that are derived from affirmative action are only symbolic, but in the political arena symbolism is often more important than substance (Williams, 1991:39).

In Suid-Afrika, sê hy, kan Gencor polities veel meer baat deur 'n paar swart topbestuurders aan te stel as deur 'n leesprogram te loods vir honderde plattelandse swartes.

Vir hom doen affirmative action positiewe skade, veral aan hulle wat dit die minste kan bekostig. Om kompensasie op rassegrondslag te eis na dekades se owerheidsdiskriminasie klink redelik. Iets ekstra is geregverdig, maar is dit reg? Op besoeke aan SuidAfrika het hy 'n goeie voorbeeld teëgekom in die debat oor die vraag of Pick 'n Pay en Checkers toegelaat moet word om supermarkte te open in swart woongebiede. Dit kan baie voordele vir swartes inhou (gerief, laer pryse, wyer verskeidenheid, ens). Die argument daarteen is dat swartes solank geweer is uit blanke areas dat swart enterpreneurs 'n geleentheid moet kry om in hul eie gebiede te ontwikkel.

Swartes se onwilligheid sit apartheid egter voort. Hy verwys na die apartheidsverbod op besigheidsregte vir Indiërs in Transvaal (Die Asiate Wet van 1939 wat via ander wette uitgeloop het op die Groepsgebiedewet van 1950). As swartes verkies om die Groepsgebiedewet voort te sit deur blankes te weer uit swart gebiede, sal hulle in die Nuwe Suid-Afrika bewys lewer daarvan dat hulle stryd nie was vir vryheid nie, maar dat die tiran wat gewettigde plundery bedryf, alleen van kleur verander het. Bowendien sal slegs ' $n$ klein groepie swart besigheidslui baat terwyl die massa die prys moet betaal ... wat presies is wat apartheid gedoen het.

As dit gaan oor arbeid klink voorkeuraanstellings geregverdig in die lig van swak onderwys- en opleidingsgeleenthede, maar, sê hy, 'n mens kan niks aan die geskiedenis doen nie behalwe om te leer om nie foute te herhaal nie. Wat hy vrees is wette wat ter wille van die opheffing van swartes die mark reguleer op die grondslag van ras. Hy verwys onder andere na die Status Quo Ooreenkoms deur die mynhuise in 1918 waar blanke unies werkerskwotas vir blankes afgedwing het. Die verbreking van die ooreenkoms het in 1922 gelei tot die Randse Opstand. Dit moet nie herhaal word nie.

Williams bepleit egter buitengewone hulp aan swartes. Niks verbied 'n bedryf om 'n swarte sonder die nodige bekwaamhede aan te stel en op te lei uit barmhartigheidsoorwegings nie. Niks verbied 'n groep werkgewers om 'n opleidingskool vir swart werknemers te open nie. As daar ekonomiese groei is, mag dit werkgewers aanspoor om te belê in hul personeel se opleiding. "Such actions by employers are well within their ownership rights, but such help should not become required by law" (Williams, 1991:41).

Koers 57(1) 1992:31.57 
Wat wel moet gebeur is dat die laaste reste van rasse- of etniese bevoordeling verwyder sal word omdat dit inherent boos en destruktief is en teen die ideaal van 'n stabiele en voorspoedige gemeenskap inwerk. Hy noem die voorbeeld van minder streng bepalings by die oprigting van huise sodat meer mense tot die mark kan toetree. "Blacks do not need gifts as much as they need the state to get out of their way" (Williams, 1991:42). Hy verwys na die taxibedryf wat sonder staatsubsidie in 'n paar jaar ontpop het nadat wetlike beperkinge verslap is. Dieselfde geld straatverkopers se posisie.

Samevattend staan hierdie swart Amerikaanse denkers vir drie doelstellings: die beëindiging van die kwotastelsel (dat affirmative action eerder op klas as ras gebaseer sal wees); die wysiging van die sosiale beleid waar vrye onderneming onderdruk word deur owerheidshulp (voordele moet gekoppel word aan poste of opleidingsprogramme: die workfare approach); die ondersteuning van swart ondersteuningsprogramme wat regeringspligte oorgee in privaat hande en die kultivering van "traditionally black values: family, self-reliance, self-restraint" om sosiale euwels soos dwelmmisbruik. tienerswangerskappe en vaderlose huise te beëindig (Lane, 1991:35)

\section{VINCENT MAPHAI - 'N SUID-AFRIKAANSE PERSPEKTIEF}

Vincent Maphai (Universiteit van Wes-Kaapland) se artikel dateer uit 1989 en dus verwys hy nog na affirmative action as 'n opsie wat nie relevant is in 'n land waar rassisme nog geïnstitusionaliseer is nie. Heelwat van sy kritiek teen die sisteem is reeds bygelê. Sy oordeel oor affirmative action is ietwat ambivalent omdat hy worstel met die dualisme kleurblind/rasbewus wat tipies is van die liberalistiese benadering (van affirmative action) met sy klem op die indiwidu. Sy fokus is voorkeuraanstellings uit benadeelde groepe. Hy beveg twee algemeen aanvaarde opvattings oor affirmative action, naamlik dat dit ontoelaatbare rassisme is en dat dit 'n egte middel is om rasseongelykheid te oorbrug in Suid-Afrika. Hy oordeel dat blankes nie 'n reg het op die poste wat hulle beklee nie en dat affirmative action oneffektief en kontraproduktief is. Hy handel dan oor gevalle waar 'n swart en wit applikant vir dieselfde pos gelyk gekwalifiseer of net minder gekwalifiseer is (Maphai, 1989:12).

Hy gebruik die Amerikaner, Thomas Nagel (Maphai, 1989:2-5), se klassifikasie van die ontwikkeling van affirmative action, naamlik: desegregasie, formele gelykheid van geleentheid, billike gelykheid van geleentheid en affirmative action. Elke stadium veronderstel die vorige. Desegregasie in Suid-Afrika behels die skrapping van apartheidswetgewing wat sal lei tot formele gelykheid voor die wet en formele gelykheid van geleentheid. Formele gelykheid beteken nie aktuele gelykheid nie. Wat nodig is, is doelbewuste pogings tot onbevooroordeeldheid. Tradisie lei tot onbewuste 
vorme van diskriminasie. Diskriminasie moet bestry word deur opvoeding en houdingsverandering in private en sosiale verhoudings. Houdingsverandering impliseer spesiale pogings om swart aansoekers te trek en die nougesette nagaan van aansoeke om diskriminasie te weer, verkieslik deur'n persoon hoër op in die hiërargie van 'n bedryf. Daarom vra fair equality 'n onderwys ter wille van effektiewe kompetisie en deelname. Dit spreek ook probleme aan wat geleenthede bemoeilik (soos armoede).

Affirmative action as die finale stadium gaan oor uiteindelike stappe wat geneem word as remediërende maatreëls nie die gewensde effek lewer nie. Hierdie stappe is nie ' $n$ plaasvervanger vir gelyke geleentheid nie, maar 'n supplement en moet wetlik afdwingbaar wees. Die doel is black advancement en enige program is aanvaarbaar wanneer dit hierdie doel verwesenlik. Black advancement maak gebruik van voorkeurbehandeling waar gelyke geleenthede nie bewerk kon word nie, en kan ' $n$ tydelike maatreël wees totdat meer fundamentele programme gelyke geleentheid bewerk. Ook Maphai beklemtoon die psigologiese skade van die verlies aan selfrespek inherent aan affirmative action. Om tussen gelyke geleentheid en affimative action te onderskei is eties dus noodsaaklik. By eersgenoemde is daar grond vir trots op wat bereik is; laasgenoemde kan lei tot sinisme oor gunste en gawes (Maphai, 1989:7).

'n Baie belangrike opmerking van Maphai gaan oor die verskil tussen die Amerikaanse en Suid-Afrikaanse situasies. In eersgenoemde was die doel om minderhede te integreer in die hoofstroom van die kultuur. In die RSA is die doel om die waardesisteem van die meerderheid in ooreenstemming met die waardesisteem van die minderheid te bring. Dit impliseer summier ' $n$ kulturele meerderwaardigheid in affirmative actionprogramme. Die onderdrukkende waardesisteem moet ten alle koste geweer word. Die Swartbewussynsbeweging in Suid-Afrika word gekenmerk deur 'n verset teen die waardesisteem van die heersende klas. "Similarly, this theme remains central in the 'Peoples' Education' movement, with its objective of eradicating certain fundamental western values such as overweening greed and individualism" (Maphai, 1989:7-8).

Maphai (1989:10) soos onder andere Graham en Leiser, gebruik die liberalistiesindiwidualistiese argument dat vir die apartheidsonreg ten koste van die ander groep gekompenseer moet word, maar dat alleen die verontregte indiwidu vergoed kan word. Die persoon wat baat by affirmative action is nic altyd dic ecn teen wie onreg gepleeg is nie. Bo 'n retrospektiewe benadering moet 'n prospektiewe benadering gevolg word van swart opheffing ter wille van swart waardigheid en die welsyn van die gemeenskap as geheel.

In hierdie konsekwensialistiese trant beklemtoon hy die noodsaaklikheid van swart leierskap in die onderwys en die ekonomie en die noodsaaklikheid van swart professionele lui as modelvoorbeelde. Volgens hom presteer swartes beter waar hulle een of 
ander model het om na te volg (Maphai, 1989:10-11). Hy oordeel dat affirmative action integrasie op universiteit en in die bedryf kan bevorder en so ongelykhede uitskakel en bydra tot 'n nie-rassige samelewing.

Dan merk hy op dat affirmative action dalk of dalk nie die ongelykheidsgaping in SuidAfrika sal vergroot. Tog is sy argumente is nie beslissend in die guns van affirmative action nie, veral teen die agtergrond van die onderskeiding tussen "fair equality of opportunity" en affirmative action. Aan die een kant beklemtoon hy die noodsaaklikheid van groter verteenwoordiging - wat bereik kan word sonder affirmative action. Aan die ander kant bepleit hy egter voorkeuraanstellings, ook in geval van minder gekwalifiseerde swart applikante.

In 'n afdeling getitel "The Morality of Affirmative Action" gaan hy in op die argument dat affirmative action verkeerd is omdat dit diskrimineer op grond van die irrelevante kriterium van kleur. Kleur kan relevant wees. Net soos 'n sokkerspeler se lengte as middelveldspeler' $n$ aanbeveling kan wees bo ander ewe-goeie spelers, kan swart-wees dit ook wees. "It would not be blackness per se that is being awarded. Rather, it is the fact that in the context, blackness is useful compared to whiteness" (Maphai, 1989:13). Hy noem dit 'n "reaction qualification". 'n Swart speler wat swakker speel as blanke spelers, kan die algemene belang van 'n blanke klub beter dien deurdat hy swart toeskouers sal trek. Al is so 'n speler "less qualified" moet hy nogtans "qualified" wees. Dit geld ook in wyer verband. Eksklusiewe blanke instellings in Suid-Afrika het in elk geval geen toekoms nie.

Wie rassediskriminasie en affirmative action op een lyn stel, verloor volgens hom uit die oog dat die doel daaragter verskil. Sodra 'n oordeel uitgaan van 'n 'hiërargiese oortuiging' oor die meerderwaardigheid van een ras teenoor ' $n$ ander, raak dit onderdrukkend en dus oneties.

'n Konsekwensialistiese benadering tot affirmative action is primêr besorgd oor die voonitgang van swartes en kan bes moontlik met ander middele as affirmative action bereik word.

Hy spreek hom ook uit oor die utilitaristiese etiek se idee dat die belange van die grootste aantal oorwegend is. Hy gee toe dat daar rede tot kommer is dat die algemene welsyn bevorder kan word ten koste van indiwiduele regte. Die konsekwensialistiese standpunt wat hy voorstaan, bevorder skynbaar juis dit: die algemene belang word gedien deur die verkragting van sommige indiwidue se regte. Volgens hom hoef affirmative action geensins so iets te impliseer nie. Hy bevraagteken dit dat elke mens 'n reg het op byvoorbeeld 'n sekere werk of 'n universiteitsloopbaan. Mense het 'n reg daarop dat daar nie teen hulle gediskrimineer sal word nie. Hy vind 'n beursskema wat 
eksklusief aan dames toegeken word, in orde omdat geen "contempt" daarby ter sprake is nie, anders as wanneer slegs Indiërs of Moslems uitgesluit sou word. Laasgenoemde sou neerkom op veragting van hulle ras en godsdiens. Samevattend: mense het 'n reg op 'n gelyke geleentheid maar nie 'n reg daarop dat ter wille van hulle teen ander gediskrimineer sal word nie.

Dat die juridiese en etiese in die konkrete werklikheid nie van mekaar geskei kan word nie, sien hy blykbaar nie in nie.

\footnotetext{
... white opposition to affirmative action cannot validly be grounded on the belief that it violates their rights. In fact, as far as affirmative action is concerned no rights are at issue at all ... affirmative action can be justifiable discrimination in favour of the underprivilcged, against those traditionally favoured by an unjust and uncqual systcm of retribution. It is justified but by the need for the advancement of the oppressed. Those who make justice or right the cenire of affirmative action discourse end up blindly rejecting or embracing the practice (Maphai, 1989:17).
}

Hierteenoor moet 'n mens stel dat diskriminasie tog 'n verkragting van distributiewe geregtigheid is. As dit dan nie gaan oor regte nie, waaroor gaan dit? Speel die ideaal van "advancement" dan nie in op onderontwikkeling as gevolg van verontregting nie? En is regsherstel nie 'n faset van opheffing nie?

Maphai probeer dan 'n verduideliking gee vir die swak prestasies van swartes. Maatskappye dig hul mislukking om te presteer dikwels toe aan ontoereikendheid; daarom is affirmative action oor die algemeen kontraproduktief. Swartes se probleme kan gewyt word aan faktore van 'n persoonlike (persoonlikheid, bekwaamheid, aanpassing), institusionele (atmosfeer van bedryf, aanpasbaarheid en ondersteuning van werkerskorps) en sosio-politieke (hantering van wegbly-aksies deur swart bestuurder) aard. Die meeste affirmative action-programme gaan uit van die veronderstelling dat swartes "defective" is. (Die woordkeuse is hier belangrik.) Hy verduidelik nie hoe dit vasgestel is dat hierdie programme van hierdie veronderstelling uitgaan nie en noem geen spesifieke programme nie. Die bestuur werk gewoonlik 'n program uit, eensydig of met die hulp van 'deskundiges' sodat swartes kan aanpas by die bedryf. Daar word geen voorsiening gemaak vir die aanpassing van die bedryf by swartes nie. Dit word dan hanteer as ' $n$ 'swart' probleem en nie as 'n menslike probleem nie. Van swartes word by voorbaat nie veel verwag nie en daar bestaan dubbele standaarde ten opsigte van die prestasies van swart en wit.

Affirmative action kan die gevolg wees van twee sosiale siektes: paternalisme en 'victimitis'. Daar word geglo dat as gevolg van apartheid swartes onherstelbare skade gely het. In so 'n geval word affirmative action 'n spesiale voorskrif deur die bedryf. Dit ondermyn die selfvertroue van die swarte in plaas van dit te laat toeneem. Swartes 
kan nooit voel dat hulle hul pos verdien het nie," they were simply beneficiaries of political expediency". Op hierdie wyse loop dit die risiko van 'n "self-perpetuating system of benevolence and dependency" (Maphai, 1989:19). Vir sowel swartes en blankes bly die regte tydstip vir die beëndiging van affirmative action 'n probleem.

Hy merk in sy artikel op dat sommige swartes ironies genoeg tot die hoogste sport geklim het sonder affirmative action (Maphai, 1989:18).

Hoe kwalifiseer hy sy program vir die uitskakeling van ongelykheid, die de-rassialisering van die gemeenskap en vir die versekering van gelyke geleenthede vir almal?

* Opheffingsprogramme moet gemeenskaplike projekte wees waar die deelnemers aan mekaar verantwoording verskuldig is. Dit veronderstel 'n plegtige binding aan die ideaal van gelyke geleentheid.

* Opheffingsprogramme moet ingestel wees op die transformering van instellings as produkte van rassisme en nie bloot op die swartes in daardie instellings nie. Swartes moet bekeer word van slawerny.

- Programme moet demokraties wees en almal betrek omdat niemand die monopolie op waarheid en geregtigheid het nie. Die waardes en etos van die nuwe SuidAfrikaanse kultuur moet onderhandel word!

* Programme sal slegs slaag as die instellings polities bewus en betrokke is. Bewussyn van begrensinge deur die regering en weerstandsbewegings is 'n moet omdat dit bepaal wat haalbaar is. Instellings moet die politieke toneel ook transendeer en 'n moontlike mikromodel voorsien aan die makro-politieke toneel (Maphai, 1989:21),

* Opheffingsprogramme moet afdwingbaar wees en nie afhanklik van welwillendheid nie. As daar nie wetlike masjienerie is nie, moet een of ander instansie (soos vakbonde) dit monitor (Maphai, 1989:23).

Sy redes vir die aanstelling van 'n swarte bo 'n witte, selfs met onvoldoende kwalifikasies, is interessant. Hy sê dis nie ongewoon nie want blankes is op dieselfde wyse vir hoe lank aangestel. Tweedens moet mens nie rigied en legalisties oor kwalifikasies wees nie (Maphai, 1989:21). Hy pleit nie vir die verlaging van standaarde by die aanstelling van personeel nie en wil geen anargisme bepleit nie, maar 'n soepel beleid, met minimumvereistes vir ' $n$ spesifieke tydstip. Soepelheid geld die toegangsfooi en nie die standaarde nie. Die funksie moet redelik goed vervul kan word. Waarom, vra hy, kom standaarde slegs ter sprake wanneer swartes betrokke is? ('n Mens sou 
kon vra waarom hy deurgaans pleit vir die opheffing van swartes?)

Sy slotsom is dat as alle gekwalifiseerde swartes goed gebruik word en gelyke geleenthede vir almal geskep word, sal affirmative action dalk nie eens nodig wees nie. Andersyds mag swartes onwillig wees om die resies te begin met 'n voorsprong wat neerbuigend toegeken is. Sowel swartes as blankes mag dit dalk verwerp - swartes omdat dit 'n onaanvaarbare gevoel van sukses in die hand werk en blankes omdat dit 'n valse gevoel van billikheid veroorsaak. "They may fear that while affimative action enhances a person's public and social image, it could easily impair his self-image. On the other hand, others might not find this feature so particularly bothersome" (Maphai, 1989:23. Vgl. 20).

Affirmative action-programme sal sorgvuldig deur onderhandeling beplan, geloods en gekontroleer moet word.

\section{BEOORDELING}

o God, U hoogste proef is nie die vuur maar die vernedering!

- Adam Small

\subsection{Regsherstel}

Die term affirmative action is oorbelaai met assosiasies wat die ideaal eerder kan verongeluk as bevorder. Tog is dit ingeburger. Saaklik gaan dit oor kompenserende geregtigheid. Tot 'n groot mate is hervorming en affirmative action sinoniem. Dit gaan immers om regsherstel op tallose terreine. Redistributiewe geregtigheid sal in die volgende dekades aktueel bly in Suid-Afrika. Op 17 Junie 1991 is die Bevolkingsregistrasiewet as die laaste grondpilaar van apartheid kragtens parlementêre stemming herroep. Dit was die afronding van die noodsaaklike, voorlopige stappe om die eerherstel van universele waardige burgerskap in Suid-Afrika te bewerk. Hierdie formele gelykheid moet nou in konkrete strukture en gesindhede waar gemaak word ter wille van fair equality.

Die klem moet dus nie op retributiewe geregtigheid val nie maar op kompensasie deur die bevordering van gelyke kanse vir alle indiwidue en groepe sodat selfrespek en wedersydse persoonseerbied bevorder kan word.

In die proses van regsherstel, moet nie verval word in die on-etiese berowing van mense van hul morele outonomie nie. 
Die etiese het immers te doen met liefde in die sin van 'n persoonseerbiedigende en persoonsbehandelende benadering van indiwidue en groepe (vgl. Heyns, 1982:8, 51/3; Smit, 1985:23-30). Hierdie benadering impliseer dat persone in hul totaliteit, met al hul behoeftes, vermoëns, geleenthede, al hul gemeenskapstrukture en al hul ideale verreken sal word. Selfrespek en selfliefde maak 'n integrale deel uit van die etiese lewenshouding. Waar persone as indiwidue en groepe onwaardig behandel en gedegradeer is deur verontregting, behoort daar een of ander vorm van restitusie te wees (vgl. Luk. 19:8, Lev. 25, Deut. 15).

Uit die analises van die swart Amerikaanse skrywers kan 'n mens aflei dat affirmative action in Suid-Afrika ook sy tol gaan eis. Nie net sal apartheid tereg verantwoordelik gehou word vir die eindelose onreg teen swartes in hierdie land nie en dus vir die groot agterstande nie, maar dit sal in baie gevalle ook die skuld moet dra vir die gebrek aan persoonlike verantwoordelikheid by baie burgers.

Om in die nuwe Suid-Afrika een ideologie met ' $n$ ander te vervang, sal tragies wees. Die woordeskat van apartheid se kontra-ideologie word oorheers deur terme soos kolonialisme, paternalisme, kapitalisme, kulturele chauvinisme. Die ellende in Afrika word steeds toegeskryf aan dieselfde sondebokke. 'n Baie nugtere ontleding van die kwaliteit van die burokrasie in die TBVC-lande en die instandhouding al dan nie van infrastruktuur, kan versoberend werk in die beoordeling van wat alles op die spel is (ten opsigte van Afrika in geheel vergelyk Strauss, 1990:111-133). Die klem behoort te verskuif van wit en swart ideologie na die bestaande probleme wat gesamentlik aangedurf sal moet word.

\subsection{Kompensasie en opvoedingsprogramme}

Die regsherstel in Suid-Afrika moet op twee vlakke bereik word: kompensasie deur buitengewone pogings om deur strukturele veranderinge gelyke geleenthede te skep (onder andere deur beter onderwys, bedryfsopleidingsprogramme en oorbruggingsonderwys) en daarnaas die ewe noodsaaklike opvoedingsprogramme ter wille van 'n mentaliteisverandering in die gemeenskap (Graham, 1988:91-96). Blankes moet ontslae raak van 'n baasskapshouding, van egorsme en kultuurchauvinisme. Swartes moet hulleself bevry van 'n 'slawementaliteit', hulle moet volledige outonomie verwerf en onafhanklik hul lewensmoontlikhede ontgin.

Wat die strukturele verandering naas 'n nuwe demokratiese grondwet betref, is een van die eerste take vir affirmative action die demokratisering van die samelewing. $V$ anselfsprekend is die staatsdiens die plek om te begin daarmee. Bewus van die taaiheid van apartheid as ' $n$ ingeburgerde mentaliteit, sal verbeeldingryke programme 
met die nodige aanmoedigingsmaatreëls geloods moet word. Hugo se voorstel vir 'n verklaring van regeringsbeleid oor gelyke werksgeleentheid in die Suid-Afrikaanse staatsdiens, gaan oor die voorsiening van gelyke geleenthede in die staatsdiens aan alle gekwalifiseerde applikante en werknemers. Vir Hugo impliseer dit enersyds wetgewing om alle diskriminasie op grond van ras, kleur, geslag of geloofsoortuiging te verbied en andersyds om gelyke werksgeleentheid te realiseer deur voortgesette affirmative actionprogramme in elke staatsdepartement (Hugo, 1990:109). As affirmative actionprogramme buitengewone pogings beteken om swartes op te lei om as gekwalifiseerde applikante mee te ding om poste en om promosie, moet dit onderskryf word.

Dat dit in sekere sektore van die staatsdiens wel tot op sekere hoogte deurgevoer is, spreek vanself, maar in die meeste bestuursposte is swartes oor die algemeen nog altyd oor die hoof gesien. Die privaatsektor het reeds veel verder gevorder hiermee (vgl. Hugo, 1990:116). In besonder sal die styl van paternalistiese konsultering vervang moet word met onderhandeling tussen gelyke gespreksgenote.

\subsection{Arbeidsprestasie en morele selfbesef}

Die uitmonding van affirmative action in die kwotastelsel moes noodwendig uitloop op verlies van arbeidskwaliteit of afname in produktiwiteit. Wanneer mense in 'n pos aangestel of toegelaat word tot 'n tersiêre inrigting op grond van hul groepsidentiteit eerder as hul kwalifikasie, moet iets ingeboet word. Die sondes van apartheid durf nie herhaal word nie. Dit gaan oor meriete. Die bes gekwalifiseerde persoon is die aangewese persoon. Arbeidsprestasie en arbeidstrots bepaal morele selfbesef. Vandaar ook die klem op persoonlike verantwoordelikheid en aanspreeklikheid in die implementering van affirmative action-programme. Suid-Afrika sit nie met'n klein minderheid verontregtes soos die VSA in die sestigerjare nie - dit gaan oor 'n meerderheid wat opgehef moet word. As affirmative action (veral in die geval van wetlike kwotas), nie gepaard gaan met 'n globale opvoedings- en opleidingsprogram nie, is die gevolge vir die wankelende ekonomie onvoorstelbaar.

Dit is belangrik vanuit 'n filosofiese perspektief om die ekonomiese kwalifikasie van 'n bedryf nooit mis te kyk nie. Indien wetgewing gerig op die herstel van die gevolge van diskriminasie die bedryf as bedryf kelder, sal dit niks bereik nie. 'n Owerheid mag 'n bedryf help om sy werkerskorps meer verteenwoordigend te maak deur hom te subsidieer met die oog op indiensopleiding en deur regeringsinsentiewe. Op dié wyse kan 'n bedryf meer produktief en dus meer mededingend gemaak word, maar slegs as daar meriete is, kan daar op die ou end wins wees. Dit sou 'n dom enterpreneur wees wat 'n meerderheid ongeskoolde mense in diens neem sonder om die koste-effektiwiteit te bereken. Dit sou ewe dom van hom wees om na te laat om op beginselgrondslag sy 
werkerskorps op te lei en te demokratiseer.

Die staat durf nie 'n bedryf se relatiewe outonomie of soewereiniteit in eie kring skend nie. In die afgelope drie jaar is soveel bedrywe ten gronde gerig en word die kanse vir 'n hoër lewenstandaard in plaas van beter, dramaties slegter. Dit beteken nie dat die staat homself kan verskoon wat die beskerming van die regte van die swart werker betref nie. Dis die essensiële taak van die staat om die regsbelange van al sy burgers te harmonieer.

Dit lyk dus verstandig om voorkeurbehandeling te beperk tot gevalle waar gelyke meriete bestaan. Die moontlikheid van aanstellings van swartes ter wille van navolgenswaardige modelle verdien aanbeveling. Ook Hugo beklemtoon dat spesiale kompenserende onderwys- en opleidingsprogramme die aangewese weg is om mense die geleentheid te gee om effektief mee te ding om 'n pos. Hy (Hugo, 1990:115) verwys na interessante statistieke in verband met die uitwissing van ongeletterdheid onder die blankes: in 1937 is $£ 8147211$ aan blanke onderwys bestee en 1677518 aan swart onderwys. "No one should be advanced beyond his or her capabilities. If this does occur, it can taint legitimate achievements. The achievements of blacks in previously white positions must be real and indisputable" (Hugo, 1990:118).

In die lig van die Amerikaanse ervaring is daar rede om te weifel as dit kom by die wetlike afdwingbaarheid van affirmative action. Hugo meen egter dat "any black advancement programme must have teeth, preferably legislative ..." en dat daar "written goals and timetables" moet wees. Hy noem meer as een keer die verpligting van sanksies en allerlei strafmaatreëls sou daar nie voldoen word aan die vereistes nie (Hugo, 1990: 116, 118).

\subsection{Onderwysvoorsiening}

Om gelyke kanse vir almal te bevorder is onderwys-voorsiening die sleutel. Geen demokrasie kan op dreef kom sonder sekere basiese kompetensies by die burgery nie. Konkreet gaan dit oor geinternaliseerde waardes soos indiwiduele outonomie, vryheid en verantwoordelikheid, gemeenskapsbetrokkenheid, regsbesef, respek vir 'n meerderheidsoordeel.

Op veel terreine word reeds gewerk aan taalvaardigheid in Engels - 'n sleutel tot hoër onderwys in die land vir die meerderheid. Hiernaas is die instelling van spesiale opleidingsprogramme noodsaaklik om te kompenseer vir agterstande in swart onderwys. Die opleidingsprogram vir swart onderwysers wat al hoe lank aan die gang is, moet meer aggressief bemark word. Veral word hier gedink aan spesiale onderwysinstellings 
Kobus Smit

wat die oorbrugging na meer gevorderde tersiêre inrigtings makliker kan maak.

Die realiteit van kultuurverskille in 'n geïntegreerde samelewing kan gehanteer word deur spesiale programme op skool, universiteit, ensovoorts. Dit kan veral effektief deur die media aangebied word. Meer geleenthede moet ook geskep word vir kommunikasie oor kultuurgrense heen (Hugo, 1990:118).

Dit gaan egter oor meer as onderwysvoorsiening. Dit gaan oor totale gemeenskapsopheffing. In hierdie verband is die kwalifikasies van Maphai ter sake.

\subsection{Verskille in lewensbeskouing}

Die basiese verskille tussen groepe in Suid-Afrika het te doen met hul lewensbeskouing. Jode en Asiate sal hier soos elders die hoogste inkomste genereer op grond van 'n lewensbeskouing (of 'natuurlike aanleg') wat hulle daartoe in staat stel. Die opheffing van swart gemeenskappe behels die kultivering van 'n waardestelsel wat nie Westersindiwidualisies-hebsugtig en ook nie tradisioneel Afrikaans-kommunaal-sosialisties sal wees nie. Wat oorweging verdien, is 'n ander werksetos wat indiwiduele prestasie beklemtoon, 'n ander siening van tyd en die bevraagtekening van daardie kante van die kommunale denk- en leefpatrone wat die etos van indiwiduele verantwoordelikheid en prestasie in gedrang bring.

\subsection{Onderwys en gemeenskaplike lewensbeskouing}

Soos Loury moet 'n mens pleit vir die aanleer van waardes. Onderwys moet ingestel wees op 'n gemeenskaplike lewensbeskouing. Met $77 \%$ Christene in Suid-Afrika is hier 'n geweldige geleentheid om die Christelike mens- en wêreldbeskouing en etos uit te dra.

Volgens Gilder is die etos wat vir Afrika gepropageer moet word dié van geloof, gesin en werk. Die Amerikaanse skrywers waarna verwys is, onderskryf dit. Dis 'n eenvoudige samevatting met onpeilbare uitdagings. Vooruitgang wat vryheid en geleentheid betref, kan nooit geskei word van welvaart nie en welvaart hang saam met 'n werksetos. Hierdie werksetos vind sy diepere grond in die waardes van die gesinslewe en uiteindelik in geloof. "Faith, in all its multifarious forms and luminosities, can by itself move the mountains of sloth and depression that afflict the world's stagnant economies (Gilder, 1981:210). Ook hy is krities oor sosiale voorsiening as die oplossing vir alle sosiale probleme: welsynsprogramme "removes the initiative to invention and ambition, and blocks the route of work, faith and family" (Gilder, 1981:122). Teenoor 
die aktiviste wat daarop hamer dat rykdom armoede skep, stel George Gilder (1981:98-99): "How much simpler than diligence and study are the formulas of expropriation! Property is theft. Hate is community. Violence is freedom. Reality is oppression."

Die smarte van Afrika is ten nouste verbonde met die probleme rondom huwelik en gesin. Lewensbeskoulike uitbouing op hierdie terrein is meer as noodsaaklik.

In Suid-Afrika moet daar ook dramatiese stappe gedoen word om valse stereotiepe persepsies af te breek en om bestaande probleme te hanteer.

Wat die mentaliteitsverandering betref (vgl. Hugo, 1986:67-69), moet verder beklemtoon word dat die uiteindelike samebindende faktor nie 'n monolitiese kuituur of 'n gemeenskaplike taal is nie, maar 'n gemeenskaplike waardesisteem wat dit alles transendeer. Die ontdekking van hierdie gemeenskaplike waardes is afhanklik van die sosiale interaksie, iets wat steeds om elke hoek en draai deur die kanker van apartheid gekortwiek word. Onbekend is onbemind. Hierdie gemeenskaplike etos wat ook hierbo bepleit is met die formule geloof, gesin en arbeid, vind sy kern natuurlik in die gebod van die naaste lief te hê soos jouself en aan ander te doen soos wat jy wil hê dat aan jou gedoen sal word. "It is love that revitalises the group identity from a fixed and static idea into a living, growing, dynamic human phenomenon that expresses the reality of the dynamism and openness of human existence" (Kriel, 1986:145).

\subsection{Vernuwing na Gods beeld}

Dit is 'n etos wat in Christus moontlik gemaak word in mense wat vernuwe is na sy beeld. Van hulle geld:

Hier is dit nie van belang of iemand Griek of Jood is nic, besny of nie besny nic, andertalig, onbeskaaf, slaaf of vry nie. Hier is Christus alles en in almal (Kol. 3:11).

Die heilige koeie van apartheid word hier in een sin gerelativeer: etnisiteit, kultuurgewoontes, taal, beskawingspeil en die implisiete sosıale stand.

Binne die konteks van die nuwe mensheid in Christus is die eerste en laaste taak van affirmative action skuldbelydenis en skuldvergiffenis ter wille van versoening en gemeenskaplike groei. 


\section{BIBLIOGRAFIE}

BUllington, R. \& PONTEROTTO, J.G. 1990. Affirmative Aclion: Definitions and Philosophy. New Directions for Students Services, 52:17-26.

FARLEY, J.E. 1982. Majority-Minority Relations. Englewood Cliffs, New Yersey : Prentice-Hall. GIDDENS, A. 1989. Sociology. Cambridge : Polity Press.

GILDER, G. 1981. Wealth and Poverty. New York : Basic Books.

GRAHAM, G. 1988. Contemporary Social Philosophy. Oxford : Basil Blackwell.

HEYNS, J.A. 1982. Tcologiese etick I. Pretoria : N.G. Kerkbockhandel Transvaal.

HITT, A. et al. 1983. Affirmative Action Effectivéness Critcria in Institutions of Higher Education. Reseanch in Higher Education, 18(2):391-408.

HUGO, P. 1986. Sins of the Fathers: Affirmative Action and the Redressing of Racial Inequality in the United States. Politikon, 13(1):54-73. Junc

HUGO, P. 1990. Affirmative Action in the Public Scrvice. ( $m$ S Schrirc, R.A. ed Critical Choices for South Africa. Cape Town : Oxford Universily Press. p. 107-125.)

KRAUTHAMMER, C. 1990. Reparations for Black Americans. Time :56. Dec. 11

KRIEL, J.R. 1986. Education for Reconciliation: Towards a Theology of Education. (In Vorster, W.S. ed. Reconciliation and Reconstruction. Pretoria : University of South Africa. p. 134-150.)

LANE, C. et al. 1991. Defying the Stereotypes. Newsweek, 15:34-35. July.

LEISER, B.M. 1981. Values in Conflicl. New York: MacMillan.

LEISER, B.M. 1986. Liberly, Juslice, and Morals. New York: MacMillan

LOURY, G.C. 1985. The Moral Ouandary of the Black Community. The Public Interest: 78.

LOURY, G.C. 1990. Black Dignity and the Common Good. First Things : Junc/July.

MAPHAI, V.T. 1989. Affirmative Action in South Africa-A Genuinc Option? Social Dynamics, $15(2): 1-24$

MAPPES, T.A. \& ZEMBATY, J.S. 1977. Social Ethics. New York : McGraw-Hill

SMIT, J.H. 1985. Elos en Elick. Blocmfontein : Patmos.

SOWELL, T. 1985. From Equal Opporlunity 10 "Affirmalive aclion". (In Schacffer, F. Is Capitalism Christian? Westchester, Illinois : Crossway Books. p. 173-192.)

SOWELL, T. 199). Preferential Politics: An International Pcrspective. Ncw York: William Morrow .

STEELE, S. 1989. Being Black and Feeling Bluc. The American Scholar, 58:497-508.

STEELE, S. 1990. White Guilt. The American Scholar, 59:497-506.

STRAUSS, G.J. 1990. Reformational Philosophy and African Culture. Bloemfontein. (Ongepubliseerde verhandeling (MA) -UOVS.)

WILlIAMS, W.E. 1991. Enlightened Discrimination. Southem African Freedom Review, 3(10):36-43. 
